\title{
Erratum
}

\section{The Decreased Cyclic-AMP-Dependent Protein Kinase A Function in the Nucleus Accumbens: A Role in Alcohol Drinking but not in Anxiety-Like Behaviors in Rats}

\section{Kaushik Misra and Subhash C Pandey}

Neuropsychopharmacology (2006) 31, 2330. doi:I 0.I038/sj.npp. I 301079

Correction to: Neuropsychopharmacology (2006) 31, 1406-1419. doi:10.1038/sj.npp.1300900

Following the publication of this article, the authors noticed the following error: in the legend for the bar diagram in
Figure 9, the gray bar should read 'NPY ( $0.5 \mu \mathrm{l}$ of $100 \mathrm{pmol})$ ' and the crossed bar should read 'NPY $(0.5 \mu \mathrm{l}$ of $100 \mathrm{pmol})+$ Rp-cAMPs $(0.5 \mu \mathrm{l}$ of $40 \mathrm{nmol})$.' 